\title{
Gambaran kadar asam urat darah pada pekerja kantor
}

\author{
${ }^{1}$ Pibi S. Darmawan \\ ${ }^{2}$ Stefana H. M. Kaligis \\ ${ }^{2}$ Youla A. Assa
}

\author{
${ }^{1}$ Kandidat Skripsi Fakultas Kedokteran Universitas Sam Ratulangi Manado \\ ${ }^{2}$ Bagian Biokimia Fakultas Kedokteran Universitas Sam Ratulangi Manado \\ Email: pibisatria@yahoo.com
}

\begin{abstract}
Prolonged hyperuricemia is the cause of gout arthritis, which has become one of burden diseases in the wide society. Several conditions can increase hyperuricemia and one of that conditions is insulin resistance associated with decreased physical activity. People with low physical activity like office workers have a higher risk of hyperuricemia. This study was aimed to describe the level of blood uric acid among office workers. This was a descriptive study with a cross-sectional design using total sampling method to obtain respondents. The results showed that there were 52 respondents in this study. Thirty eight respondents $(79,1 \%)$ had normal blood uric acid level and 14 respondents $(26,9 \%)$ had high blood uric acid level. The average of blood uric acid level was $6,09 \mathrm{mg} / \mathrm{dL}$, the median was $6.15 \mathrm{mg} / \mathrm{dL}$, the minimum and maximum values were $3 \mathrm{mg} / \mathrm{dL}$ and $9,36 \mathrm{mg} / \mathrm{dL}$ respectively, and the standard of deviation was $1,615 \mathrm{mg} / \mathrm{dL}$. Of 14 respondents with high blood uric acid level, one was female $(7.1 \%)$ and the rest were males (92.9\%). Conclusion: The majority of office workers had normal blood uric acid.
\end{abstract}

Keywords: blood uric acid, office workers.

\begin{abstract}
Abstrak: Hiperurisemia yang berkepanjangan merupakan penyebab terjadinya penyakit gout arthritis, yang telah menjadi salah satu beban penyakit dimasyarakat. Beberapa keadaan dapat meningkatkan kejadian hiperurisemia, salah satunya ialah resistensi insulin yang terkait dengan penurunan aktivitas fisik. Orang dengan aktivitas fisik yang rendah seperti pekerja kantor berisiko tinggi terhadap terjadinya hiperurisemia. Penelitian ini bertujuan untuk mengetahui gambaran kadar asam urat pada pekerja kantor. Jenis penelitian ialah deskriptif dengan metode total sampling. Hasil penelitian mendapatkan 52 pekerja kantor sebagai responden. Terdapat 38 orang $(79,1 \%)$ memiliki kadar asam urat dalam batas normal dan 14 orang $(26,9 \%)$ memiliki kadar asam urat tinggi. Nilai rerata kadar asam urat darah $6,09 \mathrm{mg} / \mathrm{dL}$, nilai median $6,15 \mathrm{mg} / \mathrm{Dl}$, nilai minimum dan maksimum pada $3 \mathrm{mg} / \mathrm{dL}$ dan $9 \mathrm{mg} / \mathrm{dL}$ serta standar deviasi $1,615 \mathrm{mg} / \mathrm{dL}$. Dari 14 responden tersebut terdapat satu orang perempuan $(7,1 \%)$ sedangkan sisanya ialah laki-laki $(92,9 \%)$. Simpulan: Sebagian besar pekerja kantor memiliki kadar asam urat darah normal.
\end{abstract}

Kata kunci: asam urat darah, pekerja kantor.

Gout merupakan penyakit muskuloskeletal akibat kelainan metabolik yang diderita oleh $1-2 \%$ populasi dunia. ${ }^{1}$ Karakteristik gout dapat berupa episode artritis akut dan artritis kronik akibat deposisi kristal monosodium urate (MSU). Penyakit ini sering ditemukan pada laki-laki usia pertengahan sampai lanjut usia dan pada perempuan post menopause. Hal ini disebabkan akibat terjadinya peningkatan kadar asam urat di atas normal dalam tubuh dan dalam darah (hiperurisemia).

Di beberapa negara kawasan Asia Tenggara didapatkan prevalensi hiper- 
urisemia sebagai berikut: Filipina 25\%, Indonesia $18 \%$, dan Thailand $9-11 \% .^{3} \mathrm{Di}$ Indonesia berdasarkan hasil RISKESDAS 2013 tidak diketahui pasti prevalensi hiperurisemia, namun diketahui prevalensi penyakit sendi, yang salah satunya disebabkan oleh gout artritis, tertinggi terdapat di Nusa Tenggara Timur 33,1\%. Di Sulawesi Utara sendiri prevalensi penyakit sendi sekitar 19,1\%. ${ }^{4}$ Untuk prevalensi hiperurisemia di daerah Minahasa Sulawesi Utara berdasarkan penelitian yang dilakukan oleh Rotty yang memiliki prevalensi $34,30 \%$ pada laki-laki dan $23,31 \%$ pada perempuan. ${ }^{5}$

Peningkatan kadar asam urat dalam darah (hiperurisemia) disebabkan oleh dua keadaan yang mengganggu keseimbangan kadar purin dalam tubuh manusia, yaitu peningkatan produksi purin dan penurunan ekskresi asam urat. Peningkatan produksi purin dapat disebabkan oleh karena konsumsi makanan tinggi purin sedangkan penurunan eksresi asam urat dapat terjadi akibat gangguan fungsi ginjal. ${ }^{2}$

Pada penurunan eksresi asam urat akibat gangguan fungsi ginjal, resistensi insulin dapat menjadi salah satu penyebab. Resistensi insulin mengakibatkan peningkatan reabsorpsi asam urat melalui perangsangan urate-anion exchanger urate transporter (URAT1) atau melalui sodiumdependent anion cotransporter pada membran brush border tubulus proksimal ginjal. Pada ginjal manusia urat diangkut melalui URAT1 melewati membran apikal dari tubulus proksimal. URAT1 diatur oleh suatu sistem melalui proses fosforilasi. Pada resistensi insulin, gangguan fosforilasi oksidatif mungkin meningkatkan konsentrasi adenosin sistemik melalui peningkatan kadar ester koenzim A dari asam lemak rantai panjang intaseluler. Peningkatan adenosin berakibat pada resistensi natrium, urat dan air. Resistensi insulin pada beberapa keadaan erat kaitannya dengan kurangnya aktivitas fisik. ${ }^{6,7}$

Penelitian Moray et al. ${ }^{8}$ didapatkan aktivitas fisik yang cenderung statis, melakukan pekerjaan berulang dan jarang melakukan aktivitas fisik identik dengan pekerja kantor. ${ }^{8}$ Berbagai aspek fisik dan psikososial pekerjaan dapat membahayakan dan menimbulkan resiko bagi kesehatan, salah satu aspek yang menjadi masalah adalah berkurangnya aktivitas fisik pada pekerja oleh karena jam kerja yang panjang. ${ }^{9}$ Hal ini membuat pekerja kantor sulit untuk mendapat aksesibilitas untuk melakukan aktivitas fisik seperti berolahraga dan menyebabkan rendahnya persepsi akan manfaat baik berolahraga sehingga dapat membahayakan dan menimbulkan risiko bagi kesehatan para pekerja kantor. ${ }^{8}$ Aktivitas fisik yang kurang pada pekerja kantor dapat menyebabkan timbulnya keadaan sindrom metabolik. Keadaan ini dapat berujung pada resistensi insulin yang dapat menyebabkan gangguan pada proses ekskresi asam urat. Penelitian ini bertujuan untuk mengetahui gambaran kadar asam urat pada pekerja kantor.

\section{METODE PENELITIAN}

Jenis penelitian ini ialah deskriptif dengan desain potong lintang yang dilaksanakan sekitar bulan AgustusDesember 2016. Penelitian ini dilakukan di PT Bank SULUTGO Manado dan pemeriksaan sampel darah dilakukan di laboratorium untuk mendapatkan hasil pengukuran kadar asam urat. Populasi penelitian ialah pekerja tata usaha perkantoran dan ditetapkan populasi target pekerja tata usaha perkantoran PT Bank SULUTGO Manado. Pengambilan sampel dilakukan dengan metode total sampling terhadap lima divisi yaitu divisi PJB, divisi umum, divisi sumber daya manusia, kantor cabang pembantu Paal 2 dan kantor cabang pembantu Tuminting PT Bank SULUTGO dan didapatkan responden berjumlah 52 orang dengan kriteria inklusi yaitu pegawai aktif di kantor bank SULUTGO dengan lama kerja $\geq 8$ jam, bersedia menjadi responden, dan menandatangani informed consent. Kriteria eksklusi yaitu tidak hadir saat dilakukan penelitian, sedang sakit saat melakukan penelitian, dan responden yang sedang mengonsumsi obat-obatan yang memengaruhi kadar asam urat.

Kadar asam urat ditentukan pada 
pemeriksaan darah vena setelah puasa 1012 jam dan diklasifikasikan dengan nilai normal pada laki-laki $2-7 \mathrm{mg} / \mathrm{dL}$ dan pada perempuan $2-6,5 \mathrm{mg} / \mathrm{dL}$.

\section{HASIL PENELITIAN}

Berdasarkan pengumpulan data pada responden, ditemukan laki-laki sebanyak 25 orang $(48,1 \%)$ dan perempuan 1-33 tahun. Responden memiliki rentang usia 22-55 tahun dan rentang masa kerja 1-33 tahun.

Hasil analisais terhadap kadar asam urat darah seluruh responden mendapatkan nilai mean $6,09 \mathrm{mg} / \mathrm{dL}$, nilai median 6,15 $\mathrm{mg} / \mathrm{dL}$, nilai standar deviasi $1,615 \mathrm{mg} / \mathrm{dL}$, serta nilai minimum $3 \mathrm{mg} / \mathrm{dL}$ dan nilai maksimum 9,36 mg/dL. Merujuk pada nilai normal laboratorium yaitu pada laki-laki yaitu 2-7 $\mathrm{mg} / \mathrm{dL}$ dan pada perempuan 2-6,5 $\mathrm{mg} / \mathrm{dL}$, didapatkan responden dengan kadar asam urat normal lebih banyak (Tabel 1).

Tabel 1. Distribusi responden berdasarkan kadar asam urat darah

\begin{tabular}{lcc}
\hline $\begin{array}{l}\text { Interperetasi } \\
\text { hasil }\end{array}$ & (n) & $\mathbf{( \% )}$ \\
\hline Normal & 38 & 73,1 \\
Tinggi & 14 & 26,9 \\
Jumlah & 52 & 100 \\
\hline
\end{tabular}

Tabel 2 menunjukkan perempuan lebih banyak memiliki kadar asam urat normal dibandingkan laki-laki, dengan nilai rerata kadar asam urat $4,92 \mathrm{mg} / \mathrm{dL}$ serta nilai minimum $3 \mathrm{mg} / \mathrm{dL}$ dan maksimum 6,35 $\mathrm{mg} / \mathrm{dL}$. Pada laki-laki dengan kadar asam urat normal didapatkan nilai rerata 6,21 $\mathrm{mg} / \mathrm{dL}$ serta nilai minimum $5,08 \mathrm{mg} / \mathrm{dL}$ dan maksimum $6,86 \mathrm{mg} / \mathrm{dL}$.

Tabel 2. Distribusi responden dengan kadar asam urat normal berdasarkan jenis kelamin

\begin{tabular}{lcc}
\hline Jenis kelamin & (n) & $\mathbf{( \% )}$ \\
\hline Laki-laki (2-7 mg/dL) & 12 & 31,6 \\
Perempuan (2-6,5 & 26 & 68,4 \\
mg/dL) & & \\
Jumlah & 38 & 100 \\
\hline
\end{tabular}

Distribusi responden hiperurisemia berdasarkan jenis kelamin ditunjukan pada
Tabel 3. Hiperurisemia didominasi oleh responden laki-laki, dengan nilai rata-rata kadar asam urat $8,26 \mathrm{mg} / \mathrm{dL}$ serta didapatkan nilai minimum $7,28 \mathrm{mg} / \mathrm{dL}$ dan maksimum 9,36 mg/dL. Pada responden perempuan hanya ditemukan satu orang responden dengan kadar asam urat 6,86 $\mathrm{mg} / \mathrm{dL}$.

Tabel 3. Distribusi responden hiperurisemia berdasarkan jenis kelamin.

\begin{tabular}{lcc}
\hline Jenis kelamin & (n) & $(\boldsymbol{\%})$ \\
\hline Laki-laki $(>7 \mathrm{mg} / \mathrm{dL})$ & 13 & 92,9 \\
Perempuan $(>6,5 \mathrm{mg} / \mathrm{dL})$ & 1 & 7,1 \\
Jumlah & 14 & 100 \\
\hline
\end{tabular}

\section{BAHASAN}

Berdasarkan hasil penelitian didapatkan sebagian besar responden memiliki kadar asam urat darah normal. Hal ini cenderung serupa dengan penelitian Chinwe et al. ${ }^{10}$ terhadap laki-laki sehat di Nigeria yang mendapatkan $64,2 \%$ responden dengan kadar asam urat normal dan $35,8 \%$ hiperurisemia. Pada penelitian oleh Singh et al. ${ }^{11}$ di Nepal terhadap 1487 responden didapatkan responden dengan kadar asam urat normal sebanyak 1240 dan sisanya sebanyak 247 responden dengan hiperurisemia.

Kadar asam urat dalam tubuh tergantung pada diet makanan yang mengandung purin, degradasi dari purin yang dibentuk secara endogen dan ekskresi di ginjal. Secara fisiologis ginjal berperan penting pada hemostasis dan ekskresi asam urat. Ginjal mengekskresikan 2/3 sampai 3/4 asam urat dalam tubuh dan sisanya sebagian besar dikeluarkan melalui usus. Kebanyakan orang dewasa memiliki kadar asam urat dalam rentang 3-7 $\mathrm{mg} / \mathrm{dL}$, dengan nilai normal pada laki-laki $<7$ $\mathrm{mg} / \mathrm{dl}$ dan pada perempuan $5,7 \mathrm{mg} / \mathrm{dL}^{2,12}$

Pada hasil penelitian didapatkan 14 responden mengalam peningkatan kadar asam urat dalam darah(hiperurisemia). Hiperurisemia dapat disebabkan oleh peningkatan konsumsi makanan tinggi purin dan gangguan pada ekskresi asam urat. Beberapa keadaan yang dapat 
memengaruhi proses ekskresi asam urat salah satu diantaranya ialah resistensi insulin. Aktivitas fisik menunjukan pengaruh terhadap sensitivitas insulin dan resistensi insulin. Pengurangan aktivitas fisik dan peningkatan konsumsi kalori dapat berlanjut menjadi terjadinya keadaan obesitas yang dapat dihubungkan dengan peningkatan asam lemak bebas dalam plasma. Hal ini mungkin terjadi pada responden yang mengalami hiperurisemia. ${ }^{2,13,14}$ Pada resistensi insulin, gangguan fosforilasi oksidatif mungkin meningkatkan konsentrasi adenosin sistemik melalui peningkatan kadar ester koenzim A dari asam lemak rantai panjang intraseluler. Peningkatan adenosin sebagai gantinya berakibat pada resistensi natrium, urat dan air. ${ }^{6}$

Penelitian oleh Sachdev ${ }^{15}$ pada populasi Rajasthan di India menunjukkan adanya hubungan antara sindrom metabolik dengan prevalensi hiperurisemia pada populasi yang diteliti. Dari penelitian yang dilakukan oleh William ${ }^{16}$ mengenai efek aktivitas fisik terhadap insiden gout pada orang sehat yang melakukan aktivitas fisik dengan intensitas berat, diperoleh informasi bahwa responden yang melakukan aktivitas fisik lebih berat (dalam penelitian ini dengan berlari lebih jauh) memiliki risiko terjadinya gout lebih rendah. Penurunan risiko berkaitan dengan penurunan kadar asam urat seiring dengan peningkatan aktivitas fisik setiap minggunya. ${ }^{15,16}$

Pada hasil penelitian disajikan distribusi responden dengan kadar asam urat darah tinggi (hiperurisemia) berdasarkan jenis kelamin. Laki-laki cenderung lebih banyak mengalami hiperurisemia dibandingkan perempuan. Penelitian yang dilakukan oleh Rodrigues et al. ${ }^{17}$ dengan studi berbasis populasi orang Brazil mendapatkan prevalensi hiperurisemia pada laki-laki $16 \%$ dan perempuan $10,7 \%$, serta penelitian meta-analisis oleh Liu et al. ${ }^{18}$ di China yang mendapatkan prevalensi hiperurisemia pada laki-laki $21,6 \%$ dan pada perempuan $8,6 \%$. Dari hasil tersebut dapat dikatakan bahwa selain faktor aktivitas fisik yang berperan terhadap kadar asam urat, jenis kelamin responden juga mempunyai pengaruh. ${ }^{17,18}$

Penelitian oleh Stockl et al. ${ }^{19}$ mendapatkan bahwa usia awal menarke, keadaan post menopause dan riwayat penggunaan kontrasepsi oral pada wanita post menopause berhubungan dengan peningkatan kadar asam urat sedangkan penelitian oleh Hak et al. $^{20}$ terhadap populasi wanita menopause didapatkan keadaan menopause berhubungan dengan peningkatan kadar asam urat dan penggunaan terapi hormon pasca menopause berhubungan pada kadar yang lebih rendah. Pada hasil penelitian gambaran kadar asam urat pada pekerja kantor ini didapatkan satu orang perempuan berusia 51 tahun yang mengalami hiperurisemia, namun tidak diketahui apakah responden telah mengalami menopause.

Pada hewan coba tikus dengan URAT1 homolog yang sudah teridentifikasi dan dilakukan analisis Western blot ditemukan bahwa ekspresi URAT1 lebih tinggi pada tikus jantan dibanding tikus betina; hal ini menunjukkan transkripsi URAT1 diatur oleh hormon seks. Sebelumnya telah diketahui bahwa kadar asam urat darah tergantung dari jenis kelamin serta estrogen meningkatkan ekskresi asan urat di ginjal. Selain hal tersebut, beberapa kelainan yang menyebabkan hiperurisemia seperti defisiensi enzim HPRT dan peningkatan aktivitas enzim PRPP merupakan kelainan terkait kromosom $\mathrm{X}$ resesif (X-linked recessive) sehingga lebih banyak didapatkan pada laki-laki. ${ }^{2,7,21}$

Dari bahasan mengenai hubungan antara resistensi insulin dan hiperurisemia didapatkan aktivitas fisik merupakan salah satu faktor yang berpengaruh. Berkurangnya aktivitas fisik akibat jam kerja yang panjang menjadi salah satu aspek fisik dan psikososial pekerjaan yang dapat membahayakan dan menimbulkan risiko kesehatan. Penelitian oleh Berniell ${ }^{22}$ menyatakan bahawa terdapat hubungan antara jam kerja dan aktivitas fisik serta kebiasaan pekerja dan menyimpulkan bahwa pengurangan jam kerja bermanfaat 
bagi kesehatan pekerja. American College of Rheumatology (ACR) mengeluarkan rekomendasi spesifik mengenai kesehatan secara umum, diet dan gaya hidup bagi pasien gout yang disebabkan oleh keadaan hiperurisemia berkepanjangan berupa penurunan berat badan untuk pasien dengan obesitas, konsumsi makanan sehat dan pembatasan konsumsi purin, berhenti merokok, hidrasi yang baik dan melakukan aktivitas fisik. ${ }^{9,22,23}$

Limitasi penelitian ini ialah tidak adanya informasi mengenai pola makan (daily food record) untuk mengetahui asupan makanan yang mengandung purin pada responden. Telah diketahui bahwa diet tinggi purin merupakan salah satu penyebab terjadinya hiperurisemia. Penggunaan informasi mengenai pola makan (daily food record) mungkin menyebabkan perbedaan hasil penelitian dengan penelitian sebelumnya atau yang akan dilakukan di masa akan datang. Selain itu penelitian ini tidak memiliki informasi indeks masa tubuh (IMT) responden dan data riwayat menopause pada responden perempuan.

\section{SIMPULAN}

Berdasarkan penelitian ini dapat disimpulkan sebagian besar pekerja kantoran memiliki kadar asam urat dalam batas normal.

\section{SARAN}

Disarankan untuk responden dengan hasil normal agar mempertahankan kadar asam urat dalam batas normal serta pengaturan pola makan dan aktivitas fisik. Untuk responden dengan hasil hiperurisemia agar dapat melakukan tindakan pencegahan hiperurisemia berkepanjangan dengan obat-obatan dan pengaturan pola makan serta aktivitas fisik

Penelitian selanjutnya dilakukan dengan menggunakan daily food record dan dengan populasi yang lebih besar serta pekerjaan yang lebih bervariasi

\section{UCAPAN TERIMA KASIH}

Ucapan terima kasih ditujukan kepada
PT Bank SULUTGO Manado yang telah mengijinkan peneliti melakukan penelitian, Laboratorium Klinik Patra yang telah membantu peneliti dalam pengolahan sampel penelitian, dan semua pihak yang telah memberikan ide, masukan, saran, dan kritik membangun untuk penyelesaian artikel.

\section{DAFTAR PUSTAKA}

1. Menken M, Munsat TL, Toole JF. The Global Burden of Disease Study. Ann Rheum Dis. 2014;73(6):949-50.

2. Burns CM, Wortmann RL. Disorder of purine \& pyrimidine metabolism. In: Kasper DL, Fauci AS, Hauser SL, Longo DL, Jameson JL, Loscalzo J, editors. Harrison's: Principle of Internal Medicine (19th ed). McGrraw-Hill, 2015.

3. Smith E, March L. Global Prevalence of Hyperuricemia: A Systematic Review of Population-Based Epidemiological Studies. Arthritis Rheumatol. 2015;67 (suppl 10).

4. Balai Penelitian dan Pengembangan Kemenkes. Riset Kesehatan Dasar. 2013.

5. Karimba A, Kaligis S, Purwanto D. Gambaran kadar asam urat pada mahasiswa angkatan 2011 Fakultas Kedokteran Universitas Sam Ratulangi dengan Index Massa Tubuh $\geq 23 \mathrm{~kg} / \mathrm{m} 2$. eBm. 2013;1(1):122-8.

6. Choi HK, Mount DB, Reginato AM. Pathogenesis of gout. Ann Intern Med. 2005;143(7):499-516.

7. Hedinger MA, Johnson RJ, Miyazaki H, Endou H. Molecular Physiology of Urate Transport. Physiology. 2005; 20(2): 125-33.

8. Moray FA, Rattu JAM, Josephus J. Faktorfaktor yang berhubungan dengan aktivitas fisik pada pegawai PT. Bank Negara Indonesia (BNI) cabang manado tahun 2015. Pharmacon. 2016;5:290-95.

9. Waddell G, Burton AK. Is work good for your healthand well-being?,(1st ed). London: The Stationary Office, 2006; p.1-3,70-1.

10.O Chinwe E, Uchechukwu D, Uchechukwu E, Joel O, Linus O, Babatunde A, et al. Prevalence of hyperuricemia and its risk factors in healthy male adults from Abakaliki metropolis, Nigeria. J Mol Pathophysiol. 2015;4(3). 
11.Singh $\mathbf{P}$, Khan S, Mittal RK. Prevalence of Hyperuricemia at Nepalgunj Medical College, Banke, Nepal. World J. Med. Sci. 2013;8(1):52-5.

12. Meisenberg G, Simmons WH. Principles of Medical Biochemistry (3rd ed). Philadelphia: Elsevier Inc, 2012; p. 471.

13. Bruno CM, Pricoco G, Cantone D, Marino E, Bruno F. Tubular handling of uric acid and factors influencing its renal excretion: a short review. EMJ Nephrol 2016;(July):92-7.

14. Horowitz JF, Klein S. Lipid metabolism during endurance exercise. Am J Clin Nutr. 2000;72(suppl):558-63

15. Sachdev B. Prevalence of Hyperuricemia and Its Relation with Metabolic Syndrome in A Select Nomad Tribal Populations of Rajasthan, India. International Journal of Health Sciences \& Research. 2012;2:25-32.

16. Williams PT. Effects of diet, physical activity and performance, and body weight on incident gout in ostensibly healthy and vigorously active men. Am J Clin Nutr. 2008;87:1480-7.

17. Rodrigues SL, Baldo MP, Capingana DP, Magalhães P, Miranda E, Bisi C, et al. Gender Distribution of Serum Uric Acid and Cardiovascular Risk Factors: Population Based Study. Arq Bras Cardiol. 2011.

18. Liu B, Wang T, Hn Z, Ww Y, Hp Y, Cx L, et al. The prevalence of hyperuricemia in China: a meta-analysis. BMC Public Health 2011;11:832.
19. Stockle D, Do A, Thorand B, Heier M. Reproductive Factors and Serum Uric Acid Levels in Females from the General Population: The KORA F4 Study. 2012;7(3). Available from :http://journals.plos.org/plosone/article? id $=10.1371 /$ journal.pone .0032668 cited: 18 November 2016

20.Hak AE, Choi HK. Research article Menopause, postmenopausal hormone use and serum uric acid levels in US women - The Third National Health and Nutrition Examination Survey. 2008;10(5):1-7 Available from: http://arthritisresearch.com/content/10/5/R116 cited: 18 November 2016

21. Rodwell VW. Metabolisme Nukleotida Purin \& Pirimidin. In: Murray RK, Granner DK, Rodwel VW, editors. Biokimia Harper (27th ed). Pendit BU, alih bahasa Indonesia. Wulandari $\mathrm{N}$, editor edisi bahasa Indonesia. Jakarta: EGC, 2006; p. 311.

22. Berniell MI. The effect of working hours on health status and health behaviors [Thesis]. Universidad Internacional Menendez Pelayo; 2012.

23. Khanna D, Fitzgerald JD, Khanna PP, Bae S, Singh MK, Neogi T, et al. 2012 American college of rheumatology guidelines for management of gout. part 1: Systematic nonpharmacologic and pharmacologic therapeutic approaches to hyperuricemia. Arthritis Care Res. 2012;64(10). 